\section{Den kliniske samtalens kraft}

White M

Kart over narrativ praksis

266 s, ill. Oslo: Pax, 2009. Pris NOK 349

ISBN 978-82-530-3195-8

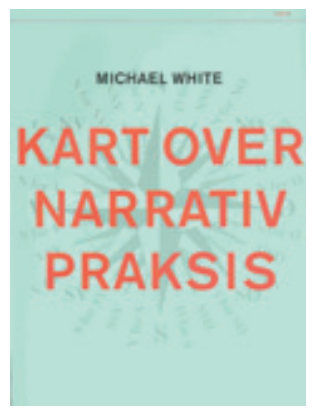

Michael White (1948-2008) var en innflytelsesrik australsk sosialarbeider og familieterapeut som underviste og inspirerte mange norske terapeuter. Han regnes som grunnleggeren av narrativ terapi, en terapeutisk retning som springer ut av narrativ teori. Teorier om kunnskap som historiefortelling har hatt innflytelse i mange humanistiske disipliner, slik som litteraturteori, systemteori og sosialpsykologi gjennom de siste tiårene.

Narrativ terapi tar utgangspunkt i menneskers behov for å finne mening i livet gjennom identitetsskapende fortellinger. Terapeuten arbeider ikke med pasientenes sykdommer, symptomer og problemer som egenskaper ved personligheten, men med deres fortellinger om problemer. Oppgaven blir å hjelpe pasienten til å bearbeide fortellingen og dens virkninger slik at den mister sin problemskapende effekt i vedkommendes liv. Med et slikt syn på pasientfortellingen følger vektlegging av samtaleprosessen, terapeutens tilhørerrolle og måter å lytte og stille spørsmål på for å føre fortellingen frem. Blant familieterapeutene i den narrative tradisjonen finner man, ikke uventet, flere dyktige og særdeles fantasifulle samtalepartnere. Retningens utøvere har derimot ikke alltid vist interesse for empirisk etterprøvning av resultatene som oppnås, og de har vært kritisert for å relativisere alvorlige problemer.

Michael White er spesielt kjent for begrepet «eksternaliserende samtaler», der han løsriver problemkomplekser eller symptomer for å kunne samtale om dem på en måte som unngår å gjøre dem til egenskaper ved personen som søker hjelp. Han hevdet at han gjennom slike samtaler kunne unngå å objektivere pasientens identitet. Gjennom samtalene ville han tydeliggjøre problemet, avgrense det og utdype pasientens forhold til det, med sikte på å omarbeide vedkommendes forhold til problemet.

Michael White har skrevet om dette i flere tidligere bøker. Det nye i denne er at han har benyttet en ny pedagogisk vinkling når han presenterer en bred tilnærming til klinisk samtale, basert på sin egen forkjærlighet for kart. Han ser kart som konstruksjoner som kan brukes som rettesnor i samtaler, ikke som rettesnor for veien å gå, men som bidrag til bevissthet om valgmuligheter i terapeutiske samtaler. Han omtaler eksternaliserende samtaler, men har også flere andre perspektiver på terapi.

Som i tidligere bøker er det lett å bli fascinert av hans kasuistikker. Ikke minst synes jeg samtalene med symptombærende barn og deres foreldre er godt beskrevet, med tenksomme kommentarer til egne vurderinger underveis. Når eksemplene er hentet fra samtaler med barn og foreldre som strever med AD/HD-diagnose eller enkoprese, blir relevansen for en norsk allmennpraktiker tydelig.

For egen del blir jeg mindre fascinert av kartene enn av vurderingene. Kart kan nok være et hjelpemiddel til å få oversikt i samtalen og bidra til å differensiere tenkningen omkring den. Dette har de til felles med mange andre teoribygninger og abstraksjoner. Men de beveger seg et godt stykke unna forfatterens evne til fantasifull frihet og impulsive kraft i samtale.

Kart over narrativ praksis egner seg dårlig for den som uten annen familieterapibakgrunn ønsker å orientere seg i dette feltet. Her vil jeg heller anbefale en norsk bok. Men den vil være av interesse for allmennpraktikere, psykiatere, barneleger og barnepsykiatere som har noe kjennskap til familieterapeutisk tradisjon og som ønsker mer innsikt i Whites inspirerende perspektiver på terapeutisk samtale.

\section{Per Stensland}

Sogndal Legesenter

\section{Dyptpløyende om strafferettslig tilregnelighet}

Radovic S, Anckarsäter $\mathrm{H}$, red.

Tillräknelighet

283 s. Lund: Studentlitteratur, 2009.

Pris SEK 249

ISBN 978-91-44-05546-6

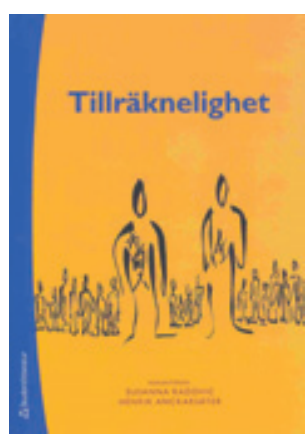

Målgruppen er meget vid, på omslaget angis $\ll .$. alla som är interesserade av människors ansvar för sina handlingar ...». Med en historisk og beskrivende utgivelse om kjerneområdet i strafferettspsykiatrien - tilregnelighet - er

forfatternes intensjon å komme med et kritisk debattinnlegg i Sveriges pågående diskusjon om dette begrepet. Som sådan er målgruppen i høyeste grad også påvirkningskraftige personer innen psykiatri, jus, filosofi og det politiske liv. Tillräknelighet tar utgangspunkt $i$ et område der svensk lovgivning og praksis har vært vesentlig annerledes enn i de fleste andre land siden midten av 1960-årene. I stedet for slik det er i Norge, der utilregnelige personer (aktivt psykotiske, «bevisstløse» eller høygradig utviklingshemmede på gjerningstiden) ikke anses som strafferettslig ansvarlige og ikke kan dømmes til fengsel, har Sverige i dette bygd på begrepet «allvarlig psykisk störning», som er mye mer omfattende med henblikk på art og grad av psykisk forstyrrelse. Dette har også ført til kritikk fra lekfolk og politikere, som mener at mange lovbrytere ikke møter de strafferettslige konsekvenser de fortjener og at Sverige nå bør slutte seg til internasjonale felleslinjer ved å gjeninnføre tilregnelighetsprinsippet fra for 45 år siden.

Forfatterne, en professor i rettspsykiatri, en legestudent og seks filosofer med akademisk grad, gir uttrykk for usikkerhet og kritikk overfor gjeninnføringen av tilregnelighetsbegrepet. Filosofene har skrevet hvert sitt kapittel, de to medisinerne ett sammen, alt på lett forståelig svensk.

Innholdet er preget av dominansen av filosofer. Disse besitter i tillegg til sin fagkunnskap god innsikt $i$ juridiske og forvaltningsmessige forhold samt $\mathrm{i}$ interessant svensk historikk for de aktuelle lovene. Medisinernes kapittel er en god innføring i det psykiatriske perspektivet. Man er altså kritisk overfor en sterk tro på nytten av tilbakevending til tilregnelighetsprinsippet, men avviser ikke helt at dette $i$ en bevisstgjort og nyansert utforming kan være riktig. Argumentasjonene belyser allmenne problemstillinger av moralsk, juridisk, psykiatrisk og filosofisk art, og er av den grunn av vesentlig interesse også utenfor Sverige. De viktigste elementene gjelder spørsmålet om mennesket innehar fri vilje, det vil si om våre handlinger er styrt av denne (voluntaristisk) eller om vi er deterministisk programmert og i vår hjernefysiologis vold og dermed egentlig uten ansvarlighet. Denne diskusjonen er svært aktuell internasjonalt og viser klare uenigheter, selv om de fleste nok bekjenner seg til varianter av et mellomstandpunkt - kompatibilisme. I Norge er avgjørelsen om eventuell utilregnelighet som kjent knyttet til et såkalt medisinsk/biologisk prinsipp, der det ikke kreves sammenheng mellom innholdet i den sykelige tilstanden og selve forbrytelsen. Noen har tatt til orde for overgang til det psykologiske prinsipp. Dette krever slik sammenheng og/eller fravær av å forstå at man har gjort noe lovstridig, noe som imidlertid i sin tur kan føre til vanskelige psykiatriske og rettslige avveininger. Interessante momenter om dette og annet finnes i boken, som kan anbefales til kolleger med både lang og kortere fartstid.

\section{Pål Hartvig}

Kompetansesenter for sikkerhets-,

fengsels- og rettspsykiatri

Oslo universitetssykehus, Ullevål 